\title{
Hidrolisis Biomasa Lignoselulosa Untuk Xilitol
}

\author{
Awan Purnawan*, Ahmad Thontowi, Lutfi Nia Kholida, Urip Perwitasari
}

Pusat Penelitian Bioteknologi, Lembaga Ilmu Pengetahuan Indonesia (LIPI), CibinongScience Center- Botanical Garden (CSCBG),Jl.Raya Bogor Km 46 Cibinong Bogor 16911, Indonesia

\begin{abstract}
ABSTRAK
Xilitol adalah gula alkohol dengan lima atom karbon. Gula ini digunakan sebagai pemanis industri pangan dan makanan, karena memiliki karakter yang menguntungkan. Meskipun xilitol diproduksi secara industri oleh reduksi kimia D-xilosa yang berasal dari hidrolisat hemiselulosa, metode produksi ini tidak ekonomis karena persyaratan untuk D-xilosa murni, suhu tinggi, dan tekanan tinggi. Oleh karena itu, produksi xilitol melalui pendekatan bioteknologi dengan bantuan mikroorganisme menjadi fokus sebagai metode yang ekonomis dan ramah lingkungan. Selain itu, untuk meningkatkan produksi bio-xilitol, strain mikroorganisme telah mengalami strategi modifikasi genetik. Review ini menjelaskan upaya produksi xilitol dari biomasa lignoselulasa, proses perlakuan biomasa, dan mikroorganisme yang berperan dalam fermentasi xilitol
\end{abstract}

Kata kunci: lignoselulosa, pra-perlakuan, fermentasi, xilitol

\begin{abstract}
Xylitol is a sugar alcohol with five atoms of C. This sugar is used as a sweetener in the food industry and confectionary, because it has a favorable character. Although xylitol is produced industrially by the chemical reduction of D-xylose derived from hemicellulose hydrolyzate, this production method is not economical because of the requirements for pure D-xylose, high temperature, and high pressure. Therefore, the production of xylitol with a biotechnological approach with the help of microorganisms becomes the focus as an economical and environmentally friendly method. In addition, to increase bio-xylitol production, strains of microorganisms have undergone genetic modification strategies. This review article describes the latest advances made in the production of xylitol from lignocellulase biomass, biomass treatment processes, and microorganisms that play a role in xylitol fermentation.
\end{abstract}

Keywords: lignocellulose, pretreatment, fermentation, xylitol

Citation: Purnawan, A., Thontowi, A., Kholida, L. N., dan Perwitasari, U. (2021). Hidrolisis Biomasa Lignoselulosa Untuk Xilitol. Jurnal Ilmu Lingkungan, 19(3), 485-496, doi:10.14710/jil.19.3.485-496

\section{Pendahuluan}

Xilitol $\left(\mathrm{C}_{5} \mathrm{H}_{12} \mathrm{O}_{5}\right)$ adalah pemanis makanan alami yang telah digunakan sebagai pengganti sukrosa karena memiliki tingkat kemanisan yang sama, yaitu sebesar 0.8 - 1.0. Namun xilitol mempunyai nilai kalori 2.4 kalori/gram, sedangkan sukrosa 4 kalori/gram (Jain and Grover, 2015). Beberapa manfaat untuk kesehatan telah dikaitkan dengan konsumsi xilitol. Xilitol berupa serbuk kristal berwarna putih, tidak berbau yang memiliki rumus kimia $\mathrm{C}_{5} \mathrm{H}_{12} \mathrm{O}_{5}$ dengan ikatan kimia berbentuk (2R,3r,4S)-Pentena-1,2,3,4,5pentanol atau nama lainnya adalah 1,2,3,4,5pentehidroksipentan. Titik cair xilitol terletak antara $92-96^{\circ} \mathrm{C}$ dan titik didihnya $126{ }^{\circ} \mathrm{C}$, densitas xilitol sebesar 1,52 g/cm3 dengan massa mol 152,15 $\mathrm{g} / \mathrm{mol}$.Salah satu manfaat yang penting adalah dalam kesehatan mulut, mengurangi atau mencegah kerusakan gigi dengan menghambat pertumbuhan mikroorganisme (Ur-Rehman et al., 2015). Xilitol juga dapat digunakan untuk pengobatan beberapa penyakit seperti diabetes, anemia hemolitik, proses inflamasi, penyakit usus besar, cedera parenteral dan ginjal, serta untuk mencegah infeksi pernapasan, otitis media akut dan osteoporosis. Manfaat xilitol yang cukup banyak, memperluas bertambahnyapasar xilitol, termasuk aplikasi dalam industri makanan dan farmasi telah meningkat secara signifikan dalam beberapa dekade terakhir (López-linares et al., 2017). Secara tradisional, produksi xilitol pada skala besar melalui proses reduksi kimia dari D-xilosa dengan penambahan katalis nikel pada suhu tinggi dengan efisiensi konversi sekitar 50-60 \% (Ur-Rehman et al., 2015).<smiles>OC[C@@H](O)C(O)[C@H](O)CO</smiles>

Gambar 1 Rumus bangun xilitol

*Penulis Korespondensi: awantea16@gmail.com 
Pada proses kimia, suhu yang digunakan sekitar 80$140{ }^{\circ} \mathrm{C}$, tekanan diatas $50 \mathrm{~atm}$ dan diperlukan separasi serta purifikasi karena penggunaan katalis yang menjadikan proses kimia menjadi mahal. Proses bioteknologi dianggap efisien dan mengurangi biaya dalam produksi xilitol (Wei et al., 2010). Pada proses bioteknologi menggunakan mikroorganismedengan kemampuan mengubah xilosa menjadi xilitol dengan efisiensi konversi sekitar 65-85 \% (Rafiqul and Sakinah, 2012). Ragi dinyatakan mikroorganisme terbaik dalam memfermentasi xilitol. Biokonversi xilosa menjadi xilitol oleh ragi dianggap menjadi alternatif yang menarik untuk proses kimia secara komersial pada skala besar saat ini, karena membutuhkan energi yang lebih rendah (suhu dan tekanan yang diperlukan lebih ringan), berkelanjutan, dan ramah lingkungan (López-linares et al., 2017).

Produksi xilitol melalui reduksi katalitik pada larutan xilosa murni dari hidrolisat hemiselulosa. Proses bioteknologi untuk produksi xilitol menggunakan ragi untuk fermentasi xilosa, dimana konversi xilosa menjadi xilitol dilakukan oleh enzim $\mathrm{NADPH}-$ dependent xylose reductase XR) (Lee et al., 2003). Proses kimiawi melalui tahapan separasi untuk memisahkan produk dengan residu, selanjutnya melalui tahapan hidrogenasi kimia dengan tekanan dan suhu tinggi untuk menghasilkan produk berupa xilitol. Proses biologi dengan proses enzimatik melalui fermentasi mikroorganisme dengan beberapa tahapan separasi seperti sentrifugasi, adsorpsi, membran filtrasi dan proses downstream/teknologi proses pengolahan lainnya untuk menghasilkan produk akhir berupa xilitol. Tinjauan ini menyajikan wawasan tentang berbagai strategi proses pretreatmen atau praperlakuan biomassa yang digunakan baik dalam skala laboratorium, pilot atau berskala besar. Pada tulisan ini dipaparkan lebih ke arah hidrolisis biomassa lignoselulosa dengan beberapa metode, secara fisika, kimia, biologi, maupun campuran diantaranya. Proses hidrolisis ini menjadi penting untuk memperoleh monomer xilosa. Xilosa inilah yang digunakan ragi dalam metabolismenya untuk produksi xilitol.

\section{Komposisi Lignoselulosa Untuk Xilitol}

Sekarang ini biomasa banyak terdapat pada perkebunan sebagai limbah yang belum dimanfaatkan secara optimal keberadaanya. Pada biomasa tersebut banyak mengandung senyawa-senyawa selulosa, hemiselulosa dan lignin. Tanaman yang mengandung biomasa yg belum dimanfaatkan diantaranya adalah tongkol jagung, bagase tebu, jerami padi, jerami sorgum, batang tembakau dan masih banyak lagi lainnya. Limbah tanaman tersebut sekarang dapat dimanfaatkan sebagai bahan baku yang unik, untuk menghasilkan produk organik yang berkelanjutan, karena sumbernya dapat diperbaharui serta membuka rute baru untuk memproduksi bahan bakar atau produk lainnya.

Bagian struktural biomassa selulosa adalah gabungan dari rantai selulosa yang disatukan oleh ikatan hidrogen sebagai serat selulosa panjang, yang pada gilirannya disatukan dengan hemiselulosa dan lignin. Komposisi ini memungkinkan pertumbuhan tanaman yang dapat menahan perubahan cuaca dan melawan serangan oleh organisme dan serangga. Struktur kimia selulosa adalah polimer linier sederhana terdiri dari unit monomer D-glukopiranosa $\beta-(1 \rightarrow 4)$. Rantai selulosa pada primer dinding sel tanaman biasanya memiliki Derajat Polimerisasi (DP) dalam kisaran 5.000-7.500 unit monomer glukosa, sedangkan DP selulosa dari kayu sekitar 10.000 dan selulosa dari kapas sekitar 15.000 (Berlin, 2013; Dutta dan $\mathrm{Wu}, 2014)$.

Hemiselulosa umumnya diklasifikasikan menurut residu gula utama pada tulang belakang, misalnya xilan, manan, dan glukan. Xilan dan manan adalah residu yang paling umum, tergantung pada spesies tanaman, tahap perkembangan, dan jenis jaringan. Berbagai sub-kelas dari hemiselulosa dapat ditemukan, termasuk glukuronoxilan, arabinoxilan, manan linier, glukomanan, galaktomanan, galaktoglukomanan, $\beta$-glukan, dan xiloglukan.Xilan adalah polisakarida yang memiliki ikatan $\beta$ - $(1 \rightarrow 4)$-Dxilopiranosa sebagai rantai utama dan memiliki beberapa rantai samping. Tanaman sebagian besar mengandung hemiselosa sepertiganya didominasi oleh xilan (Wyman et al., 2005).

Penelitian pembuatan xilosa dari berbagai bahan baku biomassa yang mengandung lignoselulosa telah banyak dilakukan (Chandel et al.,2007; Oktaviani et al., 2019; Thontowi et al., 2020; Hermiati et al., 2020a). Adapun komposisi lignoselulosa terdiri dari gula polimer selulosa, hemiselulosa, dan makro molekul lignin (Hermiati et al., 2020b). Selulosa adalah suatu polimer yang disusun oleh homo-polisakarida Dglukosa ( $\mathrm{C}_{6}$-Heksosa) dihubungkan oleh ikatan $\beta-1,4$ glukosidik. Hemiselulosa adalah polimer heteropolisakarida yang terdiri dari gula pentosa dan heksosa (C-5 dan C-6) dengan rantai utama dibentuk oleh D-xilosa atau D-galaktosa, tergantung pada sumber biomassanya, yang bercabang dengan gula lain seperti L-arabinosa, D-asam glukuronik, D-glukosa, Dmannosa, dan molekul lainnya, seperti sebagai asam (Jorgensen et al. 2007). Sedangkan lignin adalah makromolekul kompleks yang terdiri dari unit fenil propana yang melindungi selulosa-hemiselulosa yang memberikan integritas pada struktur lignoselulosa (Canilha et al., 2008). 
Tabel 1. Komposisi biomasa lignoselulosa (Kim 2018)

\begin{tabular}{|c|c|c|c|}
\hline \multirow[t]{2}{*}{ Biomasa } & Selulosa & Hemiselulosa & Lignin \\
\hline & \multicolumn{3}{|c|}{ Bobot kering (\%) } \\
\hline Sekam Barley & 33.6 & 37.2 & 19.3 \\
\hline Serat Jagung & 14.3 & 16.8 & 8.4 \\
\hline Pericarp jagung & 22.5 & 23.7 & 4.7 \\
\hline Tangkai jagung & 37.0 & 22.7 & 18.6 \\
\hline Jerami gandum & 30.2 & 21.0 & 17.0 \\
\hline Jerami padi & 31.1 & 22.3 & 13.3 \\
\hline Jerami gandum hitam & 30.9 & 21.5 & 22.1 \\
\hline Rumput-rumputan & 39.5 & 20.3 & 17.8 \\
\hline Bagas tebu & 43.1 & 31.1 & 11.4 \\
\hline Batang bunga matahari & 33.8 & 20.2 & 17.3 \\
\hline
\end{tabular}

Catatan: Biomassa yang disajikan memiliki kadar xilan yang tinggi dalam fraksi hemiselulosa

\section{Biomassa Lignoselulosa}

Biomassa lignoselulosa (BLS), terdiri dari polimerpolimer yangberbeda dan tersusun dari polisakarida (selulosa dan hemiselulosa), polimer lignin fenol aldehida dengan zat polar dan non-polar yang terikat secara kuat(Yu. et al., 2017). Gambar 1 menunjukkan BLS memiliki penampilan fisik dan kekuatan yang berbeda, tersusun dari selulosa homopolimer, heteropolimer hemiselulosa, dan lignin (Kumar et al., 2020). Struktur BLS sangat kompleks, terikat secara kuat dan kaku terhadap hidrolisis enzimatik, sehingga dapat menghambat konversi BLS menjadi biofuel atau bioproduk lainnya. Pretreatment atau pra-perlakuan dapat membantu dalam mengatasi kekakuan alami ini, sehingga BLS menjadi lebih mudah pecah menjadi komponen-komponennya.Oleh sebab itu praperlakuan dapat meningkatkan aksesibilitas enzim hidrolisis ke selulosa dan bagian hemiselulosa yang menghasilkan gula-gula sederhana. Selanjutnya gula sederhana ini difermentasi untuk menghasilkan bahan bakar atau bioproduk lainnya (Sun et al., 2016). Adapun polifenol lignin dan hidrolisat lainnya dapat dikonversi menjadi bahan kimia bernilai tambah sebagai bahan kimia penting untuk aplikasi yang menguntungkan secara ekonomi.

Polimer lignoselulosa dihubungkan satu sama lain melalui ikatan khusus dan berkontribusi $70 \%$ dari total biomassa. Karakteristik kekuatan biomassa dari konstituen polimerik tergantung pada variasi konsentrasi dari polimer. Oleh karena itu sangat mempengaruhi jenis strategi pra-perlakuan yang diterapkan untuk dekonstruksinya. Kandungan polimer biomassa yang berbeda dapat dilihat pada Tabel 2.

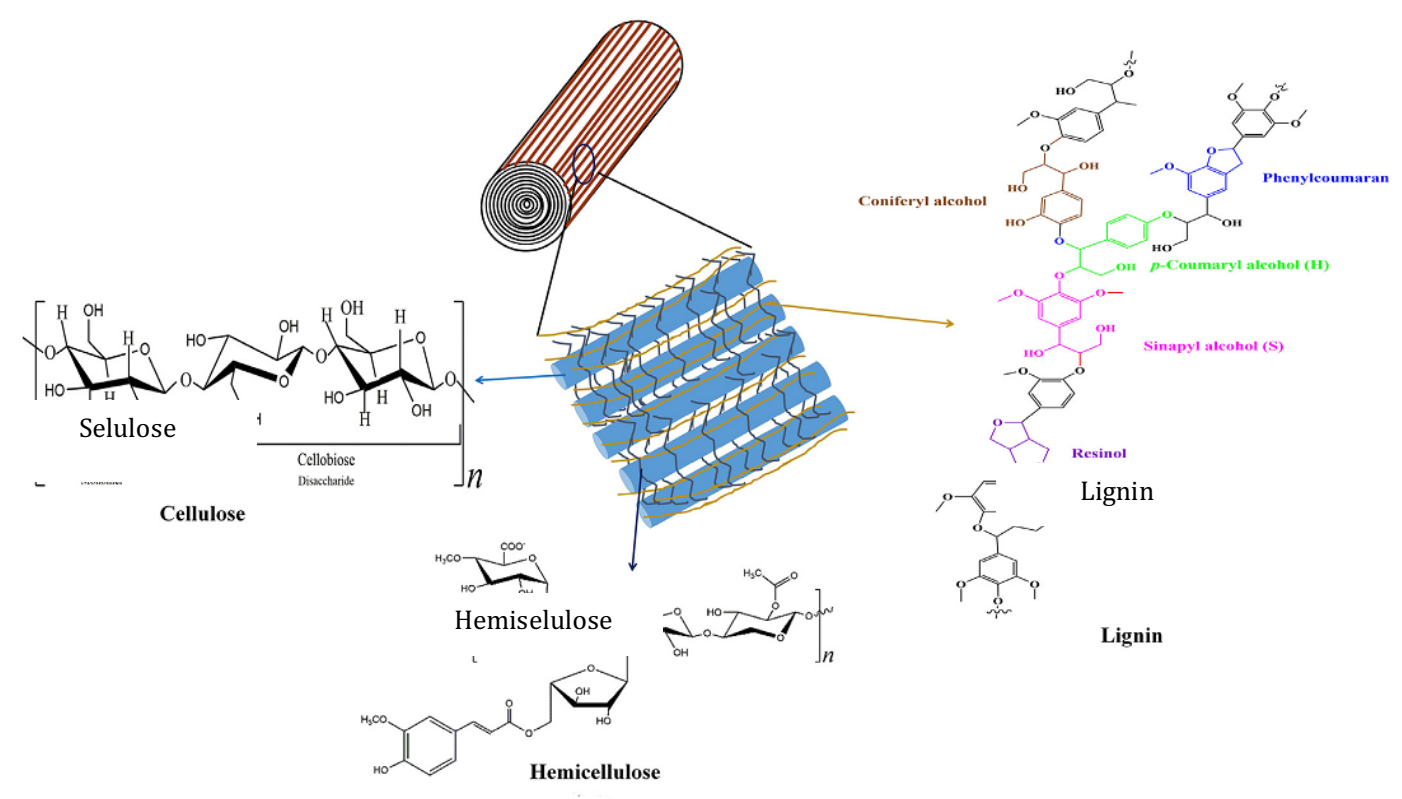

Gambar 2 Struktur selulosa, hemiselulosa, dan lignin 
Tabel 2. Fitur karakteristik selulosa, hemiselulosa dan lignin (Kumaret al.,2020)

\begin{tabular}{|c|c|c|c|}
\hline Sifat & Selulosa & Hemiselulosa & Lignin \\
\hline Struktur unit & Gugus $\beta$-D-Glukopiranosa & L-arabinosa, D-xilosa & $\begin{array}{l}\text { Siringil, guaiacil, para- } \\
\text { hidroxi-phenil }\end{array}$ \\
\hline Tingkat polimerisasi & $\sim 10.000-15.000$ & $\sim 200$ & $\sim 4000$ \\
\hline Jenis ikatan & Hidrogen & kimia & kimia \\
\hline Kristalinitas & Kristalinitas tertata tinggi & Variabel, tidak berbentuk & $\begin{array}{l}\text { Polimer 3D tidak seragam, } \\
\text { tidak linier }\end{array}$ \\
\hline Struktur & $\begin{array}{l}\text { Struktur mikro serat melipat } \\
\text { bersama untuk membentuk } \\
\text { serat kemudian bundel } \\
\text { bersama-sama menjadi serat } \\
\text { selulosa }\end{array}$ & $\begin{array}{l}\text { Rantai samping pendek } \\
\text { bersama dengan rantai } \\
\text { tulang punggung }\end{array}$ & $\begin{array}{l}\text { Unit fenil propanoid saling } \\
\text { bertautan } \\
\text { jenis obligasi }\end{array}$ \\
\hline
\end{tabular}

\section{Metode Pra-perlakuan Secara Kimia}

Pra-perlakuan adalah metode atau langkah terpenting dalam efisiensi biaya konversi BLS menjadi xilitol. Pemilihan pra-perlakuan yang tepat sangat mempengaruhi biaya biorefineri berbasis bahan baku lignoselulosa. Dalam beberapa dekade terakhir metode pra-perlakuan biomassa telah diidentifikasi, dievaluasi, dikembangkan dan dipraktikan/diujicobakan di skala laboratorium, pilot atau industri. Proses konversi bahan lignoselulosa menjadi xilitol terdiri atas tiga tahap, yaitu praperlakuan, sakarifikasi atau hidrolisis selulosa menjadi gula-gula sederhana, dan fermentasi gulagula sederhana menjadi xilitol. Selanjutnya, dilakukan pemurnian xilitolmelalui distilasi dan dehidrasi untuk memperolehxilitol murni. Menurut Hermiati et al., (2010), pra-perlakuan bertujuan untuk menghilangkan lignin, mengurangi kristalinitas selulosa dan meningkatkan porositas bahan. Namun, pada proses ini perlu biaya tinggi. Untuk mengurangi biaya produksi tinggi, telah diteliti berbagai proses agar dapat menurunkan biaya operasional tinggi tersebut. Langkah langkah yang telah diteliti dalam pra-perlakuan adalah dengan mereaksikan BLS dengan bahan-bahan kimia berupa: berbagai asam (sulfat, klorida, fumarat, malenat); basa/alkali ( $\mathrm{NaOH}, \mathrm{KOH}, \mathrm{NH}_{4} \mathrm{OH}, \mathrm{Ca}(\mathrm{OH})_{2}$ ), dan garam garam logam yang biasa disebut dengan metode pra-perlakuan.

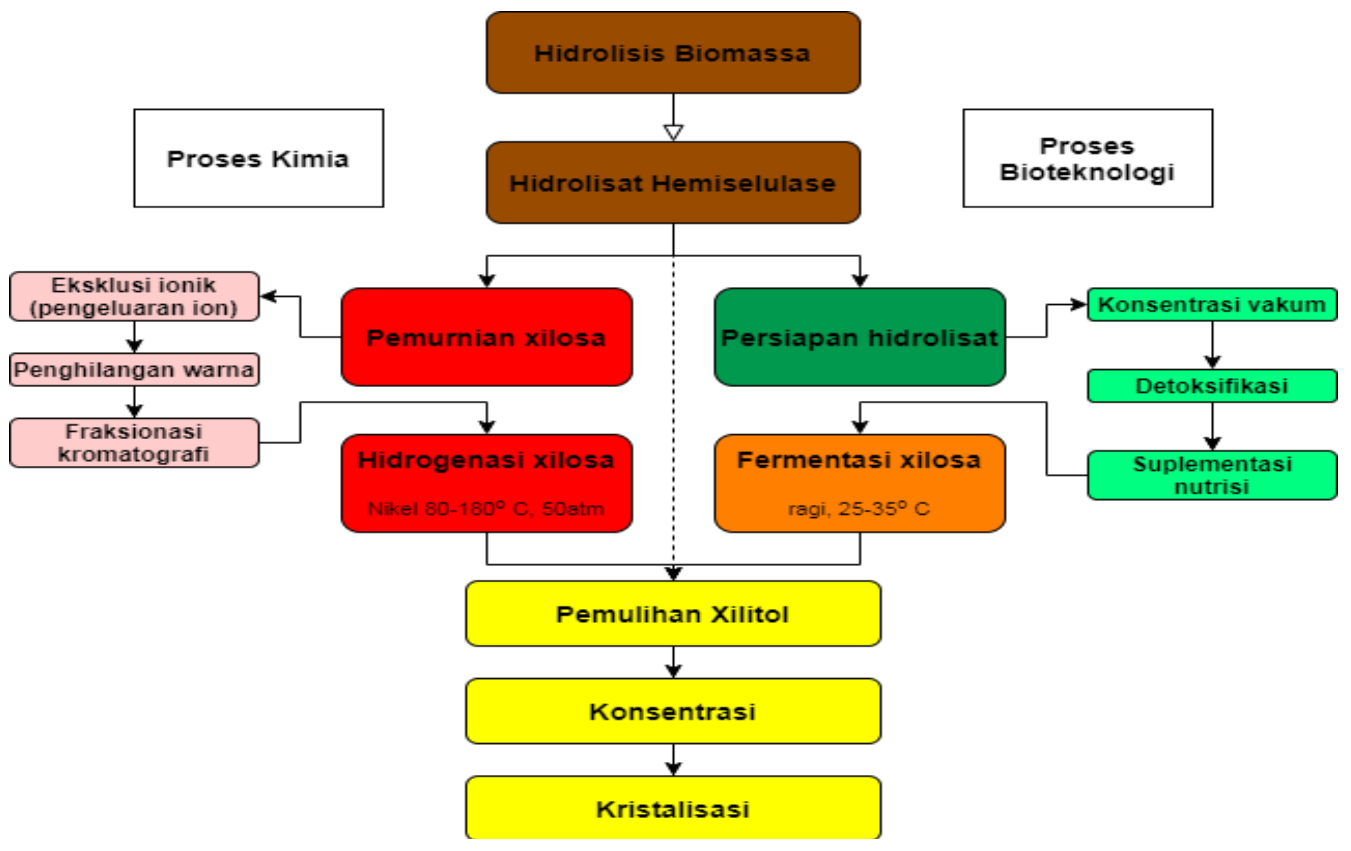

Gambar 3 Proses kimia dan bioteknologi untuk produksi xilitol dari biomassa. (Canilha et al.,2013; Hou-Rui 2012; Pal et al., 2016). 


\subsection{Pra-perlakuan Asam}

Pra-perlakuan dengan asam telah dipelajari sebelumnya secara ekstensif. Asam dapat melarutkan hemiselulosa, meningkatkan porositas biomasa dan membuat selulosa lebih mudah diakses oleh serangan enzim (Bai et al., 2016). Suhu untuk pra-perlakuan asam encer berkisarantara $120-200{ }^{\circ} \mathrm{C}$, tergantung pada tingkat kebutuhan pra-perlakuan. Kombinasi dari suhu rendah dengan konsentrasi asam tinggi atau suhu tinggi dengan konsentrasi asam rendah biasanya lebih disukai. Asam organik (asam asetat, asam format, dan asamoksalat), serta asam anorganik (asam klorida, asam maleat, nitrat, nitrit, orto-fosfat, dan asam sulfat) digunakan untuk dekonstruksi biomassa (Kumar, 2018).

Asam yang biasa digunakan paling banyak adalah asam klorida dan asam sulfat. Tao et al., (2017) menunjukkan pra-perlakuan asam klorida encer Triarrhena lutarioriparia menghasilkan 1,34 kali lipat peningkatan hidrolisis enzimatik dengan total pengurangan hasil gula $100,14 \mathrm{mg} / \mathrm{g}$ biomassa dibandingkan dengan yang tidak digunakan. Penggunaan asam sulfat encer $(0,5 \%)$ menghasilkan gula pereduksi $457 \mathrm{mg} / \mathrm{g}$ dari Zizania pra-perawatan latifolia. Pada pra-perlakuan asam, menghasilkan produk samping beberapa senyawa yang dapat menghambat fermentasi seperti furfural dan hidroximetil furfural. Oleh karena itu pemilihan asam yang tepat, konsentrasi, pengaturan waktu reaksi, dan suhu sangat membantu dalam meminimalkan senyawa inhibitor. Liu et al., (2016) menunjukan dua tahap proses, di mana pra-perlakuan $\mathrm{HCl}$ encer $(0,7 \%), 120$ ${ }^{\circ} \mathrm{C}$ selama 40 menit, diikuti oleh penggilingan jagung (selama 15 menit) dari brangkasan jagung menghasilkan gula sederhana yang tinggi ( $81 \%$ xilosa dan $64 \%$ glukosa).

Kemudian, kelompok riset yang sama An et al., (2017) menyarankan pada metode pra-perlakuan dua tahap, di mana brangkasan jagung pertama menjadi asam dioksan diikuti oleh asam klorida encer. Tahap pertama lignin dihilangkan, diikuti oleh hidrolisis hemiselulosa menghasilkan glukosa yang lebih tinggi $(91,5 \%)$ dan xilosa $(79,7 \%)$. Bahkan pada dosis selulase rendah menghasilkan 3 FPU/g substrat. Hasil penelitian tersebut penting untuk mendukung data bahwa pelarutan lignin dan hemiselulosa adalah penting untuk meningkatan hidrolisis fraksi selulosa dari biomassa lignoselulosa. Kerugian dari praperlakuanasam adalah sifatnya yang korosif, sehingga dibutuhkan reaktor non logam yang mahal, proses kompleks yang dapat meningkatkan biaya produksi.Selain itu sifat asam toksik, sehingga dibutuhkan air yang banyak untuk menetralkan, dan menghasilkan air limbah yang harus di daur ulang. Turunan furfural dan hidroksil-metil furfural dapat bertindak sebagai inhibitor fermentasi, tetapi inhibitor ini dapat dipulihkan untuk aplikasi lebih lanjut dalam menghasilkan nilai tinggi bahan kimia .

\subsection{Pra-perlakuan Basa}

Langkah pra-perlakuan dengan penambahan senyawa basa dapat merusak struktur lignin dan ikatan-ikatan lainnya (ester, aril-eter, dan ikatan C-C) yang terikat kuat pada polimer lignin dan karbohidrat. Sehingga dengan rusaknya ikatan-ikatan kimia oleh basa, membuat matrik heterogen lebih mudah diakses oleh enzim dalam proses fermentasi. Pra-perlakuan basa biasanya dilakukan dengan menggunakan senyawa seperti $\mathrm{NaOH}, \mathrm{KOH}, \mathrm{Ca}(\mathrm{OH})_{2}, \mathrm{NH}_{4} \mathrm{OH}$, dan lainnya. Proses dilakukan pada suhu kamar untuk waktu yang lebih lama atau suhu tinggi untuk waktu yang lebih singkat. Pra-perlakuan ini menyebabkan pembengkakan pada selulosa (Wen et al., 2014), kemudian menjadi rusak.Reaksi saponifikasi dapat meningkatkan porositas biomassa, gangguan dalam hubungan silang antara hemiselulosa dan lignin/selulosa. Penggunaan basa dapat memperluas area permukaan, sehingga mudah diakses, mengurangi kristalinitas selulosa, gangguan lignin, menghilangkan gugus asetil, dan membelah asam uronat (Agbor et al., 2011; Zhao et al., 2012). Natrium hidroksida digunakan paling umum untuk berbagai macam pra-perlakuan biomasa dari turunan bioetanol, bio-butanol, dan biohidrogen (Antonopoulou et al., 2016; Battista et al., 2015; Nges et al., 2015). Penggunaan $\mathrm{NaOH}$ encer $2 \%$ (b/b) dengan bantuan suhu menunjukkan pelarutan lignin dalam sekam padi $54 \%$ (b/b). Metode ini sangat efisien dan adanya peningkatan konsentrasi selulosa hingga 51,65 \% (b/b) disertai dengan kelarutan hemiselulosa rendah berkisar 10,7-33,1 \% (b/b) (Shahabazuddin et al., 2018). Penggunaan $\mathrm{NaOH}$ berlebih dapat berakibat sebagai inhibitor dalam fermentasi dan memiliki dampak kerusakan lingkungan (Chandra et al., 2015).

Daur ulang katalis senyawa basa setelah praperlakuan dapat meningkatkan efisiensi biaya dan meminimalkan dampak kerusakan lingkungan (Chen, 2012). Metode pra-perlakuan basa kekurangannya adalah tidak efisien pada biomasa berkadar lignin tinggi seperti kayu. Kerugian lainnya adalah waktu tinggal yang lama, pengolahan pasca pra-perlakuan mahal, seperti netralisasi bubur hasil pra-perlakuan (Wan et al., 2011) meningkatkan polisakarida yaitu (82,8 \% xilan dan $71,5 \%$ glukan) dan penghapusan lignin $(86,1 \%)$.

\subsection{Pra-perlakuan Selain Asam dan Basa}

Pra-perlakuan selain asam dan basa telah di kembangkan pula pra-perlakuan secara kimia lain yaitu: pra-perlakuan oksidasi, oksidan utama yang digunakan adalah oksigen, ozon, dan hidrogen peroksida. Oksidasi mengakibatkan pembelahan lignin, penghancuran hemiselulosa menjadi gula dan turunannya asam organik sebagian selulosa. Praperlakuan berbasis pelarut, pra-perlakuan organo solven memanfaatkan pelarut organik seperti metanol, 
etanol, aseton, etilen glikol. Pra-perlakuan Deep eutectic solvents (DES), campuran DES disiapkan dengan kombinasi donor ikatan hidrogen (alkohol, amida, dan asam karboksilat) dan akseptor ikatan hidrogen (kuaterner garam amonium) pada suhu sedang $\left(60-80^{\circ} \mathrm{C}\right)$. Campuran ini terdiri dari ion nonsimetris yang memiliki titik leleh dan kisi energi rendah (Satlewal et al., 2018; Sarmad et al., 2017). Ionic liquid (IL) pretreatment, IL biasanya terdiri dari kation organik besar dan anion anorganik kecil (titik lebur: $100^{\circ} \mathrm{C}$ ). Senyawa-senyawa tersebut bisa melarutkan karbohidrat dan lignin polimer BLS melalui pemutusan ikatan hidrogen yang mengganggu jaringan rumit interaksi non-kovalen antara selulosa, hemiselulosa, dan lignin (Ninomiya et al., 2012). Hydrotropic pretreatment, adalah proses reaksi kimia yang mengandung gugus fungsi hidrofilik dan hidrofobik yang dapat melarutkan senyawa tersebut dalam larutan biomassa. Beberapa senyawa hydrotropic adalah natrium benzoat, natrium simenesulfonat, natrium fenolulfonat, natrium naftalena sulfonat, natrium salisilat, natrium xilena sulfonat, dan natrium toluenasulfonat; Saltspretreatmen adalah praperlakuan dengan senyawa-senyawa garam, beberapa penelitian menunjukkan bahwa senyawa garam logam dapat mengkatalisasi dekonstruksi BLS (Liu et al., 2009). Prinsip dasar dari Saltspretreatmen adalah pembentukan asam Lewis dengan logam kompleks dalam air. Kation logam ini bertindak sebagai asam Lewis yang dapat memecahkan ikatan glikosida pada hemiselulosa kemudian menghasilkan xilosa.

\subsection{Metode Pretreatment Biohidrolisis}

Selain menggunakan katalis kimia, hidrolisis biomassa lignoselulosa juga dapat menggunakan katalis biologi (biohidrolisis). Katalis yang digunakan dalam biohidrolisis biomassa lignoselulosa dapat berupa mikroorganisme maupun enzim. Parameter yang mempengaruhi hidrolisis lignoselulosa secara biologi adalah jenis biomassa, suhu inkubasi, waktu inkubasi, kelembapan, jenis mikroorganisme, aerasi, $\mathrm{pH}$, konsentrasi inokulum, serta ukuran partikel (Sindhu et al., 2015). Mikroorganisme penghidrolisis lignoselulosa paling banyak berasal dari kelompok fungi yang biasa dikenal dengan wood-rot fungi. Identifikasi jamur yang dapat menghidrolisis kayu telah lama dilakukan. Sebanyak 126 spesies jamur pelapuk telah dilaporkan dapat melakukan pembusukan kayu. Secara umum jamur tersebut dibagi menjadi tiga kelompok, yaitu jamur pelapuk coklat, jamur pelapuk putih, dan jamur pelapuk lunak. Jamur pelapuk lunak lebih baik dalam menghidrolisis hemiselulosa dan pektin (Kumar et al., 2018), sedangkan Jamur pelapuk putih menghidrolisis lignin lebih baik dibandingkan dengan jenis jamur pelapuk lainnya (Madadi dan Abbas, 2017; Floudas et al., 2020).

Selain fungi, mikroorganisme yang dapat menghidrolisis ligninoselulosa yaitu kapang seperti
Neurospora discrete, Fusarium solani, Penicillium chrysogenum, Fusarium oxysporum. Kemampuan kapang tersebut dalam menghidrolisis lignin tidak sampai $30 \%$ (Madadi dan Abbas, 2017). Mikroorganisme pendegradasi lignin dari kelompok bakteri yaitu Burkholderia sp. Bakteri ini dilaporkan mampu menghidrolisis lignin dari batang gandum sebanyak $16 \%$ setelah 15 hari inkubasi (Yang et al., 2018). Kemampuan jamur pelapuk dalam menghidrolisis biomasa lignoselulosa disebabkan oleh produksi carbohydrate-active enzyme (CAZy) atau biasa dikenal sebagai CAZymes (Kumar et al., 2018). CAZymes dibagi menjadi beberapa kelompok seperti, enzim lignolitik, enzim selulolitik, enzim hemiselulotik, dan pektinase (Kumar et al., 2018). Enzim lignolitik berperan dalam memecah struktur kayu sedangkan enzim selulotik dan enzim hemiselulotik mendegradasi polisakarida menjadi gula sederhana.

Enzim lignolitik adalah enzim yang dapat memotong lignin dari lignoselulosa atau karbohidrat kompleks menjadi bentuk karbohidrat yang lebih sederhana (Kuswytasari et al., 2015). Aktivitas degradasi lignin oleh Omphalina sp. and P. ostreatus terjadi pada fase pertumbuhan fungi, miselium dari fungi tumbuh menutupi permukaan kayu dan mengeluarkan enzim-enzim yang dibutuhkan untuk mendegradasi lignin. Enzim yang pertama kali terdeteksi adalah lakase baru kemudian Mangan peroksidase $(\mathrm{MnP})$ dan lignin peroksidase (LiP) (Widiastuti et al., 2008). Penambahan induser seperti $1 \%$ veratril alkohol diketahui mampu meningkatkan produksi MnP dan $5 \%$ gliserol mampu meningkatkan aktivitas dari lakase yang dihasilkan oleh jamur pelapuk putih dari genus Trametes (Krumova et al., 2018). Mekanisme hidrolisis oleh enzim lignolitik berbeda antara satu dengan yang lain. Lignin peroksidase (LiP) bekerja dengan mengoksidasi struktur lignin nonfenolik, Mangan peroksidase (MnP) mengoksidasi senyawa fenolik dari lignin dengan cara mengoksidasi Mangan $2^{+}$menjadi Mangan $3^{+}$. LiP dan MnP memanfaatkan hidrogen peroksida sebagai oksidan dalam menghidrolisis lignin, sedangkan lakase mengoksidasi senyawa fenolik pada lignin dengan bantuan oksigen.

Xilanase dibutuhkan untuk menghidrolisis hemiselulosa yang berasal dari kayu yang keras, sedangkan mannannase digunakan untuk menghidrolisis dari kayu lunak (Álvarezet al., 2016). Aktivitas xilanase dalam menghidrolisis substratnya dapat dihambat oleh produk hidrolisis dari lignoselulosa lain seperti furan dan asam alifatik (Hidayatullah et al., 2020). Xilanase dari famili GH10EX (glycoside hydrolase family 10endo-xylanase) diketahui mampu mendegradasi biomassa lebih baik dibandingkan family GH11EX (glycoside hydrolase family 11 endo-xylanase) karena GH10EX lebih dekat pada rantai utama xilan serta bersifat termostabil $\mathrm{CHu}$ dan Saddler, 2018). Sifat xilanase yang toleran terhadap produk turunan dari hidrolisis lignoselulosa 
seperti ethanol dan senyawa fenolik dapat membantu hidrolisis lignoselulosa lebih efektif. Namun, mekanisme xilanase dalam memecah lignoselulosa secara utuh masih membutuhkan riset lebih lanjut. Pemanfaatan xilanase dalam menghidrolisis lignoselulosa banyak digunakan untuk membantu proses fermentasi pembentukan alkohol maupun gula alkohol seperti xilitol.

\section{Fermentasi Hidrolisat}

Produk hidrolisis lignoselulosa baik secara kimiawi mapun biologi dapat dimanfaatkan sebagai substrat untuk fermentasi. Fermentasi adalah proses katabolisme senyawa organik oleh bakteri anaerob atau aerob fakultatif dalam kondisi gelap dan tanpa adanya akseptor elektron melalui reaksi oksidasireduksi yang seimbang (Muller, 2001). Pemanfaatan biomasa lignoselulosa sebagai substrat fermentasi karena harganya yang relatif murah, mudah ditemukan, serta renewable. Salah satu produk fermentasi biomassa lignoselulosa adalah xilitol (Rao et al., 2016).

Xilitol merupakan gula yang sulit ditemukan atau biasa dikenal sebagai rare sugar yang dapat diproduksi secara kimiawi melalui proses hidrogenasi D-xilosa (Granström et al., 2007). Saat ini industri lebih memilih produksi xilitol melalui fermentasi biomassa oleh mikroorganisme. Mikroorganisme yang mampu memproduksi xilitol diantaranya ragi dari genus Pichia (Oh et al., 2013), Candida (Martiniano et al., 2013), Sugiyamaela (Sena et al., 2017). Jalur metabolisme gula hasil hidrolisis biomassa lignoselulosa menjadi xilitol tersaji pada Gambar 4. Mikroorganisme mampu memanfaatkan gula pentose dan heksosa dari hasil pra-perlakuan dari biomasa. Dalam aplikasi xilitol, mikroorganisme yeast mampu memetabolisme xilosa untuk menghasilkan xilitol.

Beberapa teknik fermentasi dilakukan untuk meningkatkan produksi xilitol. Seperti optimasi jenis substrat, sistem fermentasi (Simultaneous hydrolysis and fermentation (SHF) atau Simultaneous Saccharification and fermentation (SSF)), teknik kultivasi (single kultur ataupun cokultur), teknik pemberian substrat, komposisi media, dan bahkan rekayasa isolat yang digunakan untuk fermentasi (imobilisasi sel, rekayasa genetik). Pemilihan ragi untuk fermentasi merupakan hal yang penting dalam proses fermentasi xilitol. Beberapa strain ragi digunakan untuk produksi xilitol, yaitu Candida tropicalis (Misra dan Raghuwanshi., 2012; Rao et al., 2006), C. guilliermondii (Arruda et al., 2017), C. glycerinogenes (Zhang et al., 2015), C. mogii (Tochampa et al., 2005), Rhodotorula mucilaginosa (Vajzovic et al., 2012), Pichia pastoris (Cheng et al., 2014), Yamadazyma ubonensis (Junyapate et al., 2014), Scheffersomyces amazonensis (Cadete et al., 2016), dan Meyerozyma caribbica Y67 (Saputra et al., 2020). Saccharomyces cerevisiaestrain asli tidak dapat memfermentasi gula xilosa untuk membentuk xilitol, namun dengan memasukkan gen penyandi xilosa reduktase (XR) dari Scheffersomyces (Pichia) stipites, maka isolat hasil rekayasa dapat memanfaatkan xilosa untuk produksi xilitol (Oh et al., 2013). Jalur pentosa fosfat merupakan jalur utama dalam asimilasi xilosa menjadi xilitol (Ahmad et al., 2012) merekayasa gen zwf dan gnd (penyandi glucose-6-phosphate dehydrogenase (G6PDH) dan 6-phosphogluconate dehydrogenase (6-PGDH) pada jalur tersebut untuk meningkatakan produksi xilitol (Ahmad et al., 2012).

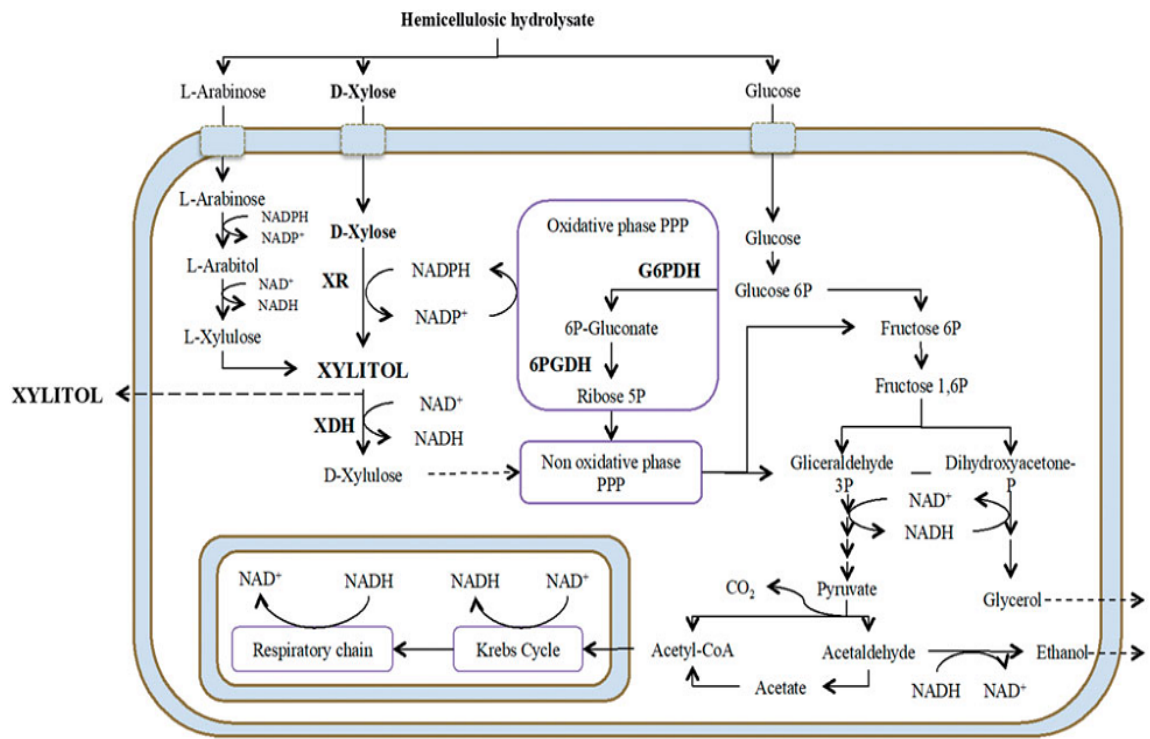

Gambar 4 Model metabolisme yang terlibat pada asimilasi xilosa dan pembentukan xilitol oleh ragi (Granströmet al.,2007). 


\section{Pemurnian Xilitol Hasil Fermentasi}

Fermentasi xilitol, baik dengan menggunakan medium sintesis maupun hidrolisat biomasa, menghasilkan produk samping yang terdiri dari bermacam-macam senyawa kimia meliputi asam asetat, gliserol, 5-HMF, dan furfural (Kresnowati et al., 2016). Dengan adanya senyawa-senyawa tersebut, maka sulit untuk dilakukan pemanfaatannya secara langsung. Oleh karena itu diperlukan proses pemurnian yang tepat dan mampu menghasilkan rendemen xilitol yang tinggi. Pemurnian xilitol juga diutamakan harus memenuhi standar keamanan pangan, karena xilitol banyak dimanfaatkan dalam pangan dan obat. Beberapa metodetelah digunakan untuk hal tersebut, antara lain pemisahan cair- cair (Mun et al., 2016), resin pengubah ion (Kitamura et al., 2019), teknologi membran (Faneer et al.,2017), dan kristalisasi (Mukherji et al., 2013).

Pemisahan xilitol hasil fermentasi bisa dilakukan dengan menggunakan pemisahan cair-cair yaitu, memindahkan komponen terlarut dari satu fase ke fase yang lain berdasarkan kelarutan, dimana fase tersebut terdiri dari fase organik dan fase air. Fase organik pada umumnya bersifat semi polar karena mampu mengikat pengotor yang berupa senyawa fenolik, yang banyak terdapat dalam hasil fermentasi yang menggunakan hidrolisat lignoselulosa. Pelarut yang sering digunakan antara lain etil asetat, kloroform, dan diklorometana. Namun, hanya etil asetat yang mampu menjernihkan larutan hasil fermentasi dan dinilai paling efektif untuk digunakan dalam pemurnian xilitol. Keuntungan menggunakan metode ini yaitu sederhana, mudah dilakukan, dan pelarut bisa digunakan secara berulang (Mun et al., 2016).

Pemurnian xilitol juga telah dilakukan dengan metode kromatografi menggunakan resin pengubah ion. Resin pengubah ion mampu menjernihkan larutan untuk mengurangi pengotor yang bersifat dapat larut dalam air, serta senyawa-senyawa inhibitor meliputi garam anorganik, asam asetat, furfural, dan 5-HMF). Penggunakan resin pengubah ion A-860S yang merupakan pengubah anion basa kuat, dan C-150 yang merupakan pengubah kation asam kuat. Pengubah anion digunakan untuk menghilangkan senyawa berwarna dari larutan gula-gulaan, sedangkan pengubah kation digunakan untuk demineralisasi, desalinasi, dan menghilangkan muatan positif dari senyawa gula-gulaan (Wei et al., 2010). Proses pemurnian dengan menggunakan siklus pada resin pengubah ion adalah sebagai berikut, resin diregenerasi dengan larutan $\mathrm{NaCl}$ atau $\mathrm{NaOH}$ untuk anion dan $\mathrm{NaCl}$ atau $\mathrm{HCl}$ untuk kation; resin dicuci dengan air deionisasi; kemudian resin digunakan untuk menjernihkan larutan hasil fermentasi; lalu, resin dicuci kembali dengan air deionisasi (Canilha et al. 2008). Kondisi optimal diperoleh pada kombinasi resin A-860S dan A-500PS, yaitu sebanyak 97.5\% produk samping dan $99.5 \%$ warna berhasil dihilangkan. Larutan hasil fermentasi yang telah jernih masih mengandung xilosa, arabinosa, gliserol, asam asetat, dan senyawa turunan lignin. Oleh karena itu, Canilha et al., (2008) melanjutkan ke tahap kristalisasi xilitol dan menghasilkan perolehan xilitol murni sebanyak $43.5 \%$ dari xilitol awal dengan tingkat kemurnian $95.9 \%$.

Teknologi pemisahan menggunakan membran juga dikembangkan untuk pemurnian xilitol. Membran separasi digunakan untuk pemurnian larutan hasil fermentasi karena dapat menghemat energi dan menghasilkan kemurnian yang tinggi. Membran polietersulfon 10,000 MWCO (molecular weight cutoff) dinilai efektif untuk ultrafiltrasi (Faneer et. al., 2017) mengkombinasikan membran tersebut dengan pluronic F127, sehingga dapat meningkatkan perembesan xilitol. Membran tersebut mampu meloloskan 82.2-90.3 \% xilitol serta menahan pengotor oligopeptida dan peptida sebanyak 49.2-53.6 $\%$. Kemurnian kristal yang diperoleh, setelah pemurnian menggunakan membran mencapai $90.3 \%$.

Metode kristalisasi pada beberapa studi, dikombinasikan dengan metode lainnya untuk memperoleh kristal xilitol sebagai produk akhir (Antunes et al., 2017). Metode ini memerlukan beberapa tahap pemurnian yaitu; adsorpsi, pemekatan dengan cara evaporasi, pengendapan, dan kemudian kristalisasi. Adsorbsi dilakukan dengan penambahan karbon aktif yang bertujuan untuk menjernihkan larutan sehingga dihasilkan kristal xilitol yang jernih dengan kemurnian tinggi. Metode ini mampu mengurangi pengotor lain seperti senyawa fenolik, asam asetat, senyawa aromatik, furfural dan 5-HMF. Wei et al., (2010) melaporkan bahwa dengan menggunakan karbon aktif, rasio penghilangan zat warna mencapai $99 \%$, sedangkan xilitol yang hilang kurang dari $5 \%$. Jika dibandingkan dengan metodeekstraksi cair-cair, penjernihan larutan hasil fermentasi xilitol menggunakan karbon aktif dinilai lebih murah, mudah, efisien, cepat, dan lebih ramah lingkungan (Wei et al, 2010; Misra dan Raghuwanshi 2011). Setelah dilakukan adsorbsi dan pemekatan, larutan hasil fermentasi kemudian dicampur etanol untuk mengendapkan xilitol dan memisahkannya dengan pengotor yang tertinggal dalam supernatan. Lalu dilarutkan kembali dengan akuades. Selanjutnya, dilakukan kristalisasi dengan mengevaporasi larutan pada suhu $30-40{ }^{\circ} \mathrm{C}$ dan ditambahkan etanol secara perlahan-lahan hingga terbentuk kristal xilitol. Untuk menambah kemurnian xilitol, kualitas dan kemurnian kristal xilitol sangat dipengaruhi oleh proses pemurnian sebelumnya, antara lain penghilangan pengotor berupa warna (umumnya dari senyawa fenolik), garam-garam mineral, dan sisa gula dan asam (Wei et al., 2010). Laporan dari Kumar (2019) dengan menggunakan kombinasi metode untuk melakukan permurnian xilitol yang diproduksi dari tongkol jagung oleh Candida tropicalis dengan proses karbonasi, pengubahan ion, dan perlakuan menggunakan karbon aktif. Proses karbonasi yaitu menyemburkan gas karbondioksida ke dalam larutan hasil fermentasi. 
Proses ini efektif untuk menghilangkan warna, kekeruhan, dan sisa asam pada larutan. Selanjutnya, larutan hasil fermentasi yang terkarbonasi tersebut dipurifikasi dengan kromatografi resin pengubah anion kuat IRN78. Konsentrasi garam dan xilitol sebelum dan sesudah purifikasi dihitung untuk mengetahui tingkat pemurniannya. Selanjutnya larutan xilitol hasil purifikasi dipekatkan dan ditambahkan karbon aktif untuk menghilangkan pengotor-pengotor lain seperti protein dan senyawa fenolik. Setelah dilakukan pemurnian dengan tiga tahap tersebut, tingkat perolehan xilitol murni adalah $78.06 \%$ dari konsentrasi awal xilitol yang diperoleh dengan kemurnian 92-94\%.

\section{Kesimpulan}

Biomassa banyak terdapat pada perkebunan sebagai limbah yang belum dimanfaatkan secara optimal keberadaanya. Struktur BLS sangat kompleks, terikat secara kuat dan kaku terhadap hidrolisis enzimatik, sehingga dapat menghambat konversi BLS menjadi biofuel. Pretreatmen atau perlakuan reaksi awal dapat membantu dalam mengatasi kekakuan alami ini, sehingga BLS menjadi lebih mudah pecah menjadi komponen-komponennya. Pra-perlakuan asam dapat melarutkan hemiselulosa, meningkatkan porositas biomasa dan membuat selulosa lebih mudah diakses oleh serangan enzim. Pra-perlakuan basa dapat memperluas area permukaan, sehingga mudah diakses, mengurangi kristalinitas selulosa, gangguan lignin, menghilangkan gugus asetil, dan membelah asam uronat. Selain asam dan basa telah dikembangkan pula pretreatment secara biohidrolisis, oksidatif, organo solven, Deep Eutectic Solvents (DES), Ionic Liquid (IL), hidrotropik, dan garam. Selain itu, kristal xilitol yang diperoleh setelah melaului tahap pemurnian harus memenuhi standar keamanan pangan karena, karena xilitol banyak dimanfaatkan dalam industri pangan dan obat.

\section{UCAPAN TERIMA KASIH}

Seluruh penulis dalam tulisan ini mempunyai kontribusi yang sama sebagai kontributor utama. Terima kasih disampaikan kepada rekan rekan kelompok penelitian Rekayasa Bioproses Pusat Penelitian Bioteknologi LIPI atas kerjasamanya.

Tabel 3. Metode pemurnian xilitol dan perolehannya (Koet al., 2008)

\begin{tabular}{|c|c|c|}
\hline Metoda & Media fermentasi dan mikroba & Hasil perolehan \\
\hline $\begin{array}{l}\text { Membran 10,000 MWCO (molecular } \\
\text { weight cutoff) polietersulfon }\end{array}$ & $\begin{array}{l}\text { Media sintesis } \\
\text { Candida boidinii (BCRC 21432), C. } \\
\text { guilliermondii (BCRC 21549), C. tropicalis } \\
\text { (BCRC 20520), C. utilis (BCRC 20334), and } \\
\text { P. anomala (BCRC 21359) }\end{array}$ & $\begin{array}{l}0.79 \mathrm{~g} / \mathrm{g} \text { xilitol oleh Candida } \\
\text { tropicalis }\end{array}$ \\
\hline $\begin{array}{l}\text { Membran HG19 10,000 MWCO } \\
\text { polisulfon }\end{array}$ & $\begin{array}{l}\text { Media sintesis Candida tropicalis (ATCC } \\
96745 \text { ) }\end{array}$ & $\begin{array}{l}87 \% \text { xilitol murni dikristalkan } \\
\text { dengan kemurnian } 90.3 \%\end{array}$ \\
\hline $\begin{array}{l}\text { Flokulasi dan adsorpsi menggunakan } \\
\text { Alumunium Poliklorida dan karbon } \\
\text { aktif } 10 \%\end{array}$ & $\begin{array}{l}\text { Hidrolisat ampas tebu } \\
\text { Candida guilliermondii }\end{array}$ & $90.3 \%$ xilitol \\
\hline Ekstraksi cair-cair & $\begin{array}{l}\text { Hidrolisat bubuk kayu Meranti } \\
\text { Candida tropicalis }\end{array}$ & $78.14 \%$ xilitol \\
\hline Ekstraksi cair-cair & $\begin{array}{l}\text { Hidrolisat ampas tebu } \\
\text { Candida guiliermondii }\end{array}$ & $\begin{array}{l}\text { Ekstraksi cair-cair } \\
99.17 \% \text { xilitol menggunakan } \\
\text { etil asetat } \\
95.41 \% \text { xilitol menggunakan } \\
\text { kloroform } \\
\text { 96.46\% xilitol menggunakan } \\
\text { diklorometana }\end{array}$ \\
\hline $\begin{array}{l}\text { a. Ekstraksi cair-cair } \\
\text { b. Karbon aktif } \\
\text { c. Kristalisasi }\end{array}$ & $\begin{array}{l}\text { Hidrolisat tongkol jagung } \\
\text { Candida tropicalis }\end{array}$ & $\begin{array}{l}47.89 \% \text { xilitol dengan } \\
\text { kemurnian } 98.99 \%\end{array}$ \\
\hline a. Karbon aktif & $\begin{array}{l}\text { Media sintesis } \\
\text { Debaryomyces hansenii }\end{array}$ & $97 \%$ xilitol \\
\hline b. Kristalisasi & $\begin{array}{l}\text { Media sintesis } \\
\text { Pichia carribica }\end{array}$ & $0.852 \mathrm{~g} / \mathrm{g}$ xilitol \\
\hline $\begin{array}{l}\text { a. Karbonasi } \\
\text { b. Resin pengubah anion IRN78 } \\
\text { c. Karbon aktif }\end{array}$ & $\begin{array}{l}\text { Hidrolisat tongkol jagung } \\
\text { Candida tropicalis }\end{array}$ & $\begin{array}{l}78.06 \% \text { xilitol kemurnian } 92- \\
94 \% .\end{array}$ \\
\hline
\end{tabular}




\section{DAFTAR PUSTAKA}

Agbor, V. B., Cicek, N., Sparling, R., Berlin, A., \& Levin, D. B. (2011). Biomass pretreatment: fundamentals toward application. Biotechnology advances, 29(6), 675-685. https://doi.org/10.1016/j.biotechadv.2011.05.005.

Ahmad, I., Shim, W. Y., Jeon, W. Y., Yoon, B. H., \& Kim, J. H. (2012). Enhancement of xylitol production in Candida tropicalis by co-expression of two genes involved in pentose phosphate pathway. Bioprocess and Biosystems Engineering, 35(1), 199-204. https://doi.org/10.1007/s00449-011-0641-9.

Álvarez, C., Reyes - Sosa, F. M., \& Díez, B. (2016). Enzymatic hydrolysis of biomass from wood. Microbial biotechnology, $9(2), \quad 149-156$. https://doi.org/10.1111/1751-7915.12346.

An, S., Li, W., Liu, Q., Li, M., Ma, Q., Ma, L., \& Chang, H. M. (2017). A two-stage pretreatment using acidic dioxane followed by dilute hydrochloric acid on sugar production from corn stover. RSC advances, 7(52), 32452-32460. https://doi.org/10.1039/C7RA05280D.

An, S., Li, W., Liu, Q., Xia, Y., Zhang, T., Huang, F., ... \& Chen, L. (2019). Combined dilute hydrochloric acid and alkaline wet oxidation pretreatment to improve sugar recovery of corn stover. Bioresource technology, 271, 283-288. https://doi.org/10.1016/j.biortech. 2018.09.126

Antonopoulou, G., Vayenas, D., \& Lyberatos, G. (2016). Ethanol and hydrogen production from sunflower straw: The effect of pretreatment on the whole slurry fermentation. Biochemical engineering journal, 116, 6574.

Antunes, F. A. F., dos Santos, J. C., da Cunha, M. A. A., Brumano, L. P., dos Santos Milessi, T. S., Terán-Hilares, R., ... \& da Silva, S. S. (2017). Biotechnological production of xylitol from biomass. In Production of Platform Chemicals from Sustainable Resources (pp. 311-342). Springer, Singapore. https://doi.org/10.1007/978-981-1041723_10.

Arruda, P. V., \& Felipe, M. G. (2009). Role of glycerol addition on xylose-to-xylitol bioconversion by Candida guilliermondii. Current microbiology, 58(3), 274-278.

Bai, X., Lant, P. A., Jensen, P. D., Astals, S., \& Pratt, S. (2016). Enhanced methane production from algal digestion using free nitrous acid pre-treatment. Renewable Energy, 88, 383-390.

Battista, F., Mancini, G., Ruggeri, B., \& Fino, D. (2016). Selection of the best pretreatment for hydrogen and bioethanol production from olive oil waste products. Renewable Energy, 88, 401-407.

Berlin, A. (2013). No barriers to cellulose breakdown. Science, 342(6165), 1454-1456.

Cadete, R. M., Melo-Cheab, M. A., Viana, A. L., Oliveira, E. S., Fonseca, C., \& Rosa, C. A. (2016). The yeast Scheffersomyces amazonensis is an efficient xylitol producer. World Journal of Microbiology and Biotechnology, 32(12), 1-5.

Canilha, L., Rodrigues, R. C. L. B., Antunes, F. A. F., Chandel, A. K., Milessi, T. S. D. S., Felipe, M. D. G. A., \& Silva, S. D. (2013). Bioconversion of hemicellulose from sugarcane biomass into sustainable products. Sustainable degradation of lignocellulosic biomass-Techniques, applications and commercialization, 1, 15-45.

Canilha, L., Carvalho, W., Giulietti, M., Felipe, M. D. G. A., \& Almeida E Silva, J. B. (2008). Clarification of a wheat straw - derived medium with ion - exchange resins for xylitol crystallization. Journal of Chemical Technology \&
Biotechnology: International Research in Process, Environmental \& Clean Technology, 83(5), 715-721. https://doi.org/10.1002/jctb.1861.

Chandel, A. K., Kapoor, R. K., Singh, A., \& Kuhad, R. C. (2007). Detoxification of sugarcane bagasse hydrolysate improves ethanol production by Candida shehatae NCIM 3501. Bioresource technology, 98(10), 19471950.

Chandra, R., Takeuchi, H., \& Hasegawa, T. (2012). Methane production from lignocellulosic agricultural crop wastes: A review in context to second generation of biofuel production. Renewable and Sustainable Energy Reviews, 16(3), 1462-1476. https://doi.org/10.1016/j.rser.2011.11.035.

Chen, X. (2012). Development of effective pretreatment and bioconversion systems for converting organic residuals to bioenergy. University of California, Davis.

Cheng, H., Lv, J., Wang, H., Wang, B., Li, Z., \& Deng, Z. (2014). Genetically engineered Pichia pastoris yeast for conversion of glucose to xylitol by a singlefermentation process. Applied microbiology and biotechnology, 98(8), 3539-3552. https://doi.org/10.1007/s00253-013-5501-x

Dutta, S., \& Wu, K. C. W. (2014). Enzymatic breakdown of biomass: enzyme active sites, immobilization, and biofuel production. Green chemistry, 16(11), 46154626.

Faneer, K. A., Rohani, R., \& Mohammad, A. W. (2017) Polyethersulfone/pluronic F127 blended nanofiltration membranes for xylitol purification. Malaysian Journal of Analytical Sciences, 21(1), 221230. https://doi.org/10.17576/mjas-2017-2101-26

Floudas, D., Bentzer, J., Ahrén, D., Johansson, T., Persson, P., \& Tunlid, A. (2020). Uncovering the hidden diversity of litter-decomposition mechanisms in mushroomforming fungi. The ISME journal, 14(8), 2046-2059. https://doi.org/10.1038/s41396-020-0667-6

Granström, T. B., Izumori, K., \& Leisola, M. (2007). A rare sugar xylitol. Part II: biotechnological production and future applications of xylitol. Applied microbiology and biotechnology, 74(2), 273-276. https://doi.org/10.1007/s00253-006-0760-4

Hermiati, E., Laksana, R. P. B., Fatriasari, W., Kholida, L. N., Thontowi, A., Arnieyanto, D. R., ... \& Watanabe, T. (2020). Microwave-assisted acid pretreatment for enhancing enzymatic saccharification of sugarcane trash. Biomass Conversion and Biorefinery, 1-18.

Hermiati, E., Oktaviani, M., Ermawar, R. A., Laksana, R. P. B., Kholida, L. N., Thontowi, A., ... \& Watanabe, T. (2020). Optimization of Xylose Production from Sugarcane Trash by Microwave-Maleic Acid Hydrolysis. Reaktor, 20(2), 81-88.

Hermiati E., D. Mangunwidjaja, C.T. Sunarti, O. Suparno, B. Prasetya 2010. Pemanfaatan Biomassa Lignoselulosa Ampas Tebu Untuk Produksi Bioetanol. Jurnal Litbang Pertanian, 29(4).

Hidayatullah, I. M., T. Setiadi, M. Tri, A. Penia, R. Boopathy. 2020. Xylanase inhibition by the derivatives of lignocellulosic material. Bioresource technology, 300, 122740. https://doi.org/10.1016/j.biortech.2020.122740.

Hou-Rui, Z. (2012). Key drivers influencing the large scale production of xylitol. In D-Xylitol (pp. 267-289). Springer, Berlin, Heidelberg.

Hu, J., \& Saddler, J. N. (2018). Why does GH10 xylanase have better performance than GH11 xylanase for the 
deconstruction of pretreated biomass?. Biomass and Bioenergy, 110, 13-16. https://doi.org/10.1016/j.biombioe.2018.01.007.

Jain, T., \& Grover, K. (2015). Sweeteners in human nutrition. International Journal of Health Sciences and Research, 5(5), 439-451.

Jørgensen, H., Kristensen, J. B., \& Felby, C. (2007). Enzymatic conversion of lignocellulose into fermentable sugars: challenges and opportunities. Biofuels, Bioproducts and Biorefining, $\quad 1(2)$ https://doi.org/10.1002/bbb.4

119-134.

Junyapate, K., Jindamorakot, S., \& Limtong, S. (2014). Yamadazyma ubonensis fa, sp. nov., a novel xylitolproducing yeast species isolated in Thailand. Antonie van Leeuwenhoek, 105(3), 471-480. https://doi.org/10.1007/s10482-013-0098-8.

Kitamura, Y., Shobu, R., Matsuura, H., Jyo, A., \& Ihara, T. (2020). Xylitol Separation from a Polyol Mixture Using Lanthanide Ion-loaded Resins. Analytical Sciences, 19N032. https://doi.org/10.2116/analsci.19N032.

Ko, C. H., Chiu, P. C., Yang, C. L., \& Chang, K. H. (2008). Xylitol conversion by fermentation using five yeast strains and polyelectrolyte-assisted ultrafiltration. Biotechnology letters, 30(1), 81-86. https://doi.org/10.1007/s10529007-9507

Kresnowati, M. T. A. P., Setiadi, T., Tantra, T. M., \& Rusdi, D. (2016). Microbial production of xylitol from oil palm empty fruit bunch hydrolysate: Effects of inoculum and pH. Journal of Engineering and Technological Sciences, 48(5), 523-533.

Krumova, E., Kostadinova, N., Miteva - Staleva, J., Stoyancheva, G., Spassova, B., Abrashev, R., \& Angelova, M. (2018). Potential of ligninolytic enzymatic complex produced by white - rot fungi from genus Trametes isolated from Bulgarian forest soil. Engineering in Life Sciences, 18(9), 692-701. https://doi.org/10.1002/elsc.201800055.

Kumar, B., Bhardwaj, N., Agrawal, K., Chaturvedi, V., \& Verma, P. (2020). Current perspective on pretreatment technologies using lignocellulosic biomass: An emerging biorefinery concept. Fuel processing technology, 199, 106244.

Kumari, D., \& Singh, R. (2018). Pretreatment of lignocellulosic wastes for biofuel production: a critical review. Renewable and Sustainable Energy Reviews, 90, 877891. https://doi.org/10.1016/j.rser.2018.03.111.

Kumar, V., Sandhu, P. P., Ahluwalia, V., Mishra, B. B., \& Yadav, S. K. (2019). Improved upstream processing for detoxification and recovery of xylitol produced from corncob. Bioresource technology, 291, 121931.

Kuswytasari, N. D., Shovitri, M., \& Zulaika, E. (2015). Ligninolytic Enzymes Produced by Gliomastix sp. in an Organic Waste Medium. IPTEK the Journal for Technology and Science, 26(1).

Larsson, S., Palmqvist, E., Hahn-Hägerdal, B., Tengborg, C., Stenberg, K., Zacchi, G., \& Nilvebrant, N. O. (1999). The generation of fermentation inhibitors during dilute acid hydrolysis of softwood. Enzyme and microbial technology, 24(3-4), 151-159. https://doi.org/10.1016/S0141-0229(98)00101-X.

Lee, J. K., Koo, B. S., \& Kim, S. Y. (2003). Cloning and characterization of the xyl1 gene, encoding an NADHpreferring xylose reductase from Candida parapsilosis, and its functional expression in Candida tropicalis. Applied and environmental microbiology, 69(10), 6179-
6188. https://doi.org/10.1128/AEM.69.10.61796188.2003

Liu, Q., Li, W., Ma, Q., An, S., Li, M., Jameel, H., \& Chang, H. M. (2016). Pretreatment of corn stover for sugar production using a two-stage dilute acid followed by wet-milling pretreatment process. Bioresource technology, 211, 435-442. https://doi.org/10. 1016/j.biortech.2016.03.131.

López-Linares, J. C., Romero, I., Cara, C., Castro, E., \& Mussatto, S. I. (2018). Xylitol production by Debaryomyces hansenii and Candida guilliermondii from rapeseed straw hemicellulosic hydrolysate. Bioresource technology, 247, 736-743. https://doi.org/10.1016/j.biortech.2017.09.139

Madadi, M., \& Abbas, A. (2017). Lignin degradation by fungal pretreatment: a review. J. Plant Pathol. Microbiol, 8(2), 1-6. https://doi.org/10.4172/2157-7471.1000398.

Misra, S., Raghuwanshi, S., Gupta, P., Dutt, K., \& Saxena, R. K. (2012). Fermentation behavior of osmophilic yeast Candida tropicalis isolated from the nectar of Hibiscus rosa sinensis flowers for xylitol production. Antonie Van Leeuwenhoek, 101(2), 393-402. https://doi.org/10.1007/s10482-011-9646-2

Mukherji, R., Joshi-Navare, K., \& Prabhune, A. (2013). Crystalline Xylitol Production by a Novel Yeast, Pichia caribbica (HQ222812), and Its Application for Quorum Sensing Inhibition in Gram-Negative Marker Strain C hromobacterium violaceum CV026. Applied biochemistry and biotechnology, 169(6), 1753-1763.

Müller, V. (2001). Bacterial fermentation. e LS.

Mun, L. W., Rafiqul, I. S. M., Sakinah, A. M. M., \& Zularisam, A. W. (2016). Purification of bioxylitol by liquid-liquid extraction from enzymatic reaction mixture. Separation Science and Technology, 51(14), 2369-2377. https://doi.org/10.1080/01496395.2016.1203335.

Nges, I. A., Li, C., Wang, B., Xiao, L., Yi, Z., \& Liu, J. (2016). Physio-chemical pretreatments for improved methane potential of Miscanthus lutarioriparius. Fuel, 166, 2935. https://doi.org/10.1016/j.fuel.2015.10.108.

Ninomiya, K., Kamide, K., Takahashi, K., \& Shimizu, N. (2012). Enhanced enzymatic saccharification of kenaf powder after ultrasonic pretreatment in ionic liquids at room temperature. Bioresource technology, 103(1), 259-265. https://doi.org/10.1016/j. biotech..10.019.

Oh, E. J., Ha, S. J., Kim, S. R., Lee, W. H., Galazka, J. M., Cate, J. H., \& Jin, Y. S. (2013). Enhanced xylitol production through simultaneous co-utilization of cellobiose and xylose by engineered Saccharomyces cerevisiae. Metabolic engineering, $15,226-234$. https://doi.org/10.1016/j.ymben.2012.09.003.

Oktaviani, M., Hermiati, E., Thontowi, A., Laksana, R. P. B., Kholida, L. N., Andriani, A., \& Mangunwardoyo, W. (2019, March). Production of xylose, glucose, and other products from tropical lignocellulose biomass by using maleic acid pretreatment. In IOP Conference Series: Earth and Environmental Science (Vol. 251, No. 1, p. 012013). IOP Publishing.

Martiniano, S. E., Chandel, A. K., Soares, L. C., Pagnocca, F. C., \& da Silva, S. S. (2013). Evaluation of novel xylosefermenting yeast strains from Brazilian forests for hemicellulosic ethanol production from sugarcane

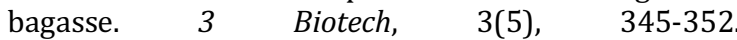
https://doi.org/10.1007/s13205-013-0145-1.

Pal, S., Mondal, A. K., \& Sahoo, D. K. (2016). Molecular strategies for enhancing microbial production of xylitol. Process Biochemistry, 51(7), 809-819. 
Palmqvist, E., \& Hahn-Hägerdal, B. (2000). Fermentation of lignocellulosic hydrolysates. II: inhibitors and mechanisms of inhibition. Bioresource technology, 74(1), 25-33. https://doi.org/10.1016/S09608524(99)00161-3

Rafiqul, I. S. M., \& Sakinah, A. M. (2012). Bioproduction of xylitol by enzyme technology and future prospects. International Food Research Journal, 19(2), 405.

Rao, R. S., Jyothi, C. P., Prakasham, R. S., Sarma, P. N., \& Rao, L. V. (2006). Xylitol production from corn fiber and sugarcane bagasse hydrolysates by Candida tropicalis. Bioresource technology, 97(15), 1974-1978. https://doi.org/10.1016/j.biortech. 2005.08.015

Rao, L. V., Goli, J. K., Gentela, J., \& Koti, S. (2016). Bioconversion of lignocellulosic biomass to xylitol: an overview. Bioresource technology, 213, 299-310. https://doi.org/10.1016/j.biortech.2016.04.092

Saputra, H., Thontowi, A., Kholida, L. N., \& Kanti, A. (2020, February). Efficiency of Xylitol Production from Meyerozyma caribbica Y67 with Cell Initiation and Volume Fermentation. In IOP Conference Series: Earth and Environmental Science (Vol. 439, No. 1, p. 012032). IOP Publishing.

Sarmad, S., Xie, Y., Mikkola, J. P., \& Ji, X. (2017). Screening of deep eutectic solvents (DESs) as green CO 2 sorbents: from solubility to viscosity. New Journal of Chemistry, 41(1), 290-301. https://doi.org/10.1039/C6NJ03140D

Sena, L. M., Morais, C. G., Lopes, M. R., Santos, R. O., Uetanabaro, A. P., Morais, P. B., ... \& Rosa, C. A. (2017). $\mathrm{d}$-Xylose fermentation, xylitol production and xylanase activities by seven new species of Sugiyamaella. Antonie van Leeuwenhoek, 110(1), 53-67.

Sindhu, R., Binod, P., \& Pandey, A. (2016). Biological pretreatment of lignocellulosic biomass-An overview.

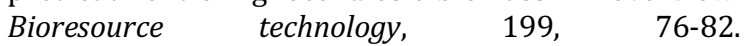
https://doi.org/10.1016/j.biortech.2015.08.030.

Shahabazuddin, M., Chandra, T. S., Meena, S., Sukumaran, R. K., Shetty, N. P., \& Mudliar, S. N. (2018). Thermal assisted alkaline pretreatment of rice husk for enhanced biomass deconstruction and enzymatic saccharification: Physico-chemical and structural characterization. Bioresource technology, 263, 199-206. https://doi.org/10.1016/j.biortech.2018.04.027.

Su, Y., Xian, H., Shi, S., Zhang, C., Manik, S. N., Mao, J., ... \& Liu, H. (2016). Biodegradation of lignin and nicotine with white rot fungi for the delignification and detoxification of tobacco stalk. BMC biotechnology, 16(1), 1-9. https://doi.org/10.1186/s12896-016-0311-8.

Sun, S., Sun, S., Cao, X., \& Sun, R. (2016). The role of pretreatment in improving the enzymatic hydrolysis of lignocellulosic materials. Bioresource technology, 199, 49-58. https://doi.org/10.1016/j.biortech.2015.08.061.

Tao, X., Li, J., Zhang, P., Nabi, M., Jin, S., Li, F., ... \& Ye, J. (2017). Reinforced acid-pretreatment of Triarrhena lutarioriparia to accelerate its enzymatic hydrolysis. International Journal of Hydrogen Energy, 42(29), 18301-18308. https://doi.org/Doi:10.1016/j.ijhydene. 2017.04.149.

Thontowi, A., Mayangsari, W., Kholida, L. N., Kanti, A., Wardani, A. K., \& Hermiati, E. (2020, February). Evaluation of Addition The Activated Charcoals and $\mathrm{pH}$
Adjustment in The Treatment of Lignocellulosic Hydrolisates for Xylitol Production. In IOP Conference Series: Earth and Environmental Science (Vol. 439, No. 1, p. 012023). IOP Publishing https://doi.org/10.1088/1755-1315/439/1/012023

Tochampa, W., Sirisansaneeyakul, S., Vanichsriratana, W., Srinophakun, P., Bakker, H. H., \& Chisti, Y. (2005). A model of xylitol production by the yeast Candida mogii. Bioprocess and biosystems engineering, 28(3), 175-183. https://doi.org/10.1007/s00449-005-0025-0

Ur-Rehman, S., Mushtaq, Z., Zahoor, T., Jamil, A., \& Murtaza, M. A. (2015). Xylitol: a review on bioproduction, application, health benefits, and related safety issues. Critical reviews in food science and nutrition, 55(11), 1514-1528.

Vajzovic, A., Bura, R., Kohlmeier, K., \& Doty, S. L. (2012). Novel endophytic yeast Rhodotorula mucilaginosa strain PTD3 II: production of xylitol and ethanol in the presence of inhibitors. Journal of Industrial Microbiology and Biotechnology, 39(10), 1453-1463. https://doi.org/10.1007 /s10295- 012-1154-5

Wan, C., Zhou, Y., \& Li, Y. (2011). Liquid hot water and alkaline pretreatment of soybean straw for improving cellulose digestibility. Bioresource technology, 102(10), 6254$6259 . \quad$ https://doi.org/10.1016/j.biortech. 2011.02.075.

Wei, J., Yuan, Q., Wang, T., \& Wang, L. (2010). Purification and crystallization of xylitol from fermentation broth of corncob hydrolysates. Frontiers of Chemical Engineering in China, 4(1), 57-64. https://doi.org/10.1007/s11705-009-0295-1

Wen, Z., Wu, M., Lin, Y., Yang, L., Lin, J., \& Cen, P. (2014). Artificial symbiosis for acetone-butanol-ethanol (ABE) fermentation from alkali extracted deshelled corn cobs by co-culture of Clostridium beijerinckii and Clostridium cellulovorans. Microbial cell factories, 13(1), 1-11. https://doi.org/10.1186/s12934-014-009

Widiastuti, H., \& Wulaningtyas, A. (2008). Activity of ligninolytic enzymes during growth and fruiting body development of white rot fungi Omphalina sp. and Pleurotus ostreatus. HAYATI Journal of Biosciences, 15(4), 140-144. https://doi.org/10.4308/hjb.15.4.140.

Wyman, C. E., Decker, S. R., Himmel, M. E., Brady, J. W., Skopec, C. E., \& Viikari, L. (2005). Hydrolysis of cellulose and hemicellulose. Polysaccharides: Structural diversity and functional versatility, 1, 1023-1062

Yang, C. X., Wang, T., Gao, L. N., Yin, H. J., \& Lü, X. (2017). Isolation, identification and characterization of lignin degrading bacteria from Qinling, China. Journal of applied microbiology, 123(6), 1447-1460. https://doi.org/10.1111/jam.13562.

Zhang, C., Zong, H., Zhuge, B., Lu, X., Fang, H., \& Zhuge, J. (2015). Production of xylitol from D-xylose by overexpression of xylose reductase in osmotolerant yeast Candida glycerinogenes WL2002-5. Applied biochemistry and biotechnology, 176(5), 1511-1527. https://doi.org/10.1007/s12010-015-1661-8

Zhao, X., Zhang, L., \& Liu, D. (2012). Biomass recalcitrance. Part II: Fundamentals of different pre - treatments to increase the enzymatic digestibility of lignocellulose. Biofuels, Bioproducts and Biorefining, 6(5), 561-579. https://doi.org/10.1002/bbb.1350 